\title{
Regucalcin, a calcium-binding protein, is a new target gene in human prostate cancer?
}

\author{
Cláudio J Maia, Cátia V Vaz, Carina G Peres, Cecília RA Santos, Sílvia Socorro* \\ From 16th International Charles Heidelberger Symposium on Cancer Research \\ Coimbra, Portugal. 26-28 September 2010
}

Regucalcin was identified as a calcium $\left(\mathrm{Ca}^{2+}\right)$-binding protein playing an important role in maintenance of intracellular $\mathrm{Ca}^{2+}$ homeostasis. More recently, proteomic studies have identified it as a down-regulated gene in mouse and human hepatocellular carcinomas. In addition, regucalcin effects in kidney and liver cells, suppressing cell proliferation, inhibiting expression of oncogenes, and increasing the expression of tumor suppressor genes, have been described.

Prostate cancer depends on the trophic effects of androgens, and altered $\mathrm{Ca}^{2+}$ homeostasis and signaling have been associated with the development of this pathology. Therefore, in the present study we analyzed regucalcin expression, in neoplasic and non-neoplasic prostate tissue and cells, by means of RT-PCR, western blot and immunohistochemistry. Regucalcin localizes in cell nuclei and cytoplasm and its expression was diminished in prostate cancer cases. Moreover, regucalcin immunoreactivity was negatively associated with cellular differentiation of prostate adenocarcinoma. The effect of the non-aromatizable androgen 5-alphadihydrotestosterone (DHT) on regucalcin expression in vitro, in $\mathrm{LNCaP}$ prostate cancer cells, and in vivo, in a rat animal model, was determined. Real-time PCR analysis showed that DHT downregulates regucalcin expression, an effect inhibited in the presence of both flutamide and cyclohexamide, suggesting the involvement of androgen receptor and de novo protein synthesis.

The loss of regucalcin expression in prostate cancer cases and the regulation of its expression by androgens suggest that it may be associated with tumor development and/or progression.

\footnotetext{
* Correspondence: ssocorro@fcsaude.ubi.pt

Health Sciences Research Centre, Covilhã, Portugal

Full list of author information is available at the end of the article
}

Published: 24 September 2010

\section{doi:}

Cite this article as: Maia et al:: Regucalcin, a calcium-binding protein, is a new target gene in human prostate cancer? BMC Proceedings 20104 (Suppl 2):P13.
Submit your next manuscript to BioMed Central and take full advantage of:

- Convenient online submission

- Thorough peer review

- No space constraints or color figure charges

- Immediate publication on acceptance

- Inclusion in PubMed, CAS, Scopus and Google Scholar

- Research which is freely available for redistribution

Submit your manuscript at www.biomedcentral.com/submit
C Biomed Central 